\title{
ПРОИЗВОДНЫЕ РОЗИНДОЛА - НОВЫЕ СОЕДИНЕНИЯ С АНТИБАКТЕРИАЛЬНОЙ И ПРОТИВОГРИБКОВОЙ АКТИВНОСТЬЮ
}

\author{
А.А. Панов \\ ФГБНУ «Научно-исследовательский институт по изысканию новых антибиотиков \\ им. Г.Ф.Гаузе» 119021, Россия, г. Москва, ул.Большая Пироговская, 11, стр. 1.
}

DOI: 10.19163/MedChemRussia2021-2021-48

E-mail:7745243@mail.ru

Образование розиндола (1) из п-диметиламинобензальдегида и индола в кислой среде используется как качественная реакция на образование бактериями индола [1]. Розиндол не обладает бактерицидными свойствами, но два известных триарилметановых красителя - малахитовый синий и бриллиантовый зелёный широко используются уже более 100 лет как антисептики. Ранее были изучены антибактериальные свойства производных три(индол-3-ил)илметилия [2].

$\mathrm{N}$-алкилзамещённые производные розиндола проявили высокую антимикробную активность. Были синтезированы и протестированы производные (аминофенил)бис(1-алкилиндол-3-ил)метилия 2 и (индолин-5-ил)бис(1-алкилиндол3-ил)метилия 3. Изучена их антибактериальная и противогрибковая активность, установлена связь между активностью и длиной алкильных заместителей. Изучены свойства их прекурсоров - производных арилбис(индол-3-ил)метана.

Высокая активность открывает широкие возможности по химической модификации с целью поиска новых антимикробных агентов.

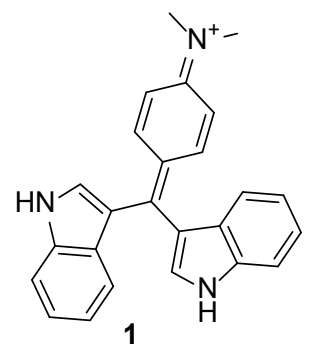

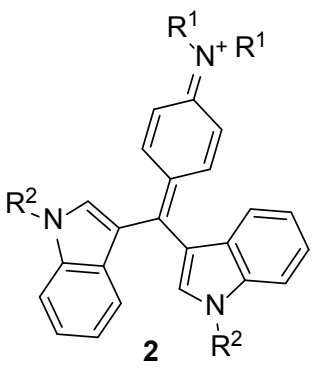<smiles>[R1]n1cc(C(c2cn([R2])c3ccccc23)=c2ccc3c(c2)CC[N+]=3[R1])c2ccccc21</smiles>

$\mathrm{R}^{1}, \mathrm{R}^{2}=$ Ethyl, Propyl, Butyl

\section{Литература}

[1] Maria P. MacWilliams. Indole test protocol. American Society for Microbiology. 2009. http://www.asmscience.org/content/education/protocol/protocol.3202

[2] S.N. Lavrenov, Y.N. Luzikov, E.E. Bykov et al. Bioorg. Med. Chem. 2010, 18, 6905-6913.

[3] A.A. Panov, S.N. Lavrenov, E.P., Mirchink, E.B. Isakova, A.M. Korolev, A.S. Trenin, J. Antibiot. 2021, 74(3), 219-224. 